\title{
PENGARUH MODEL PEMBELAJARAN WEB (e-LEARNING) BERNUANSA LINGKUNGAN BERBANTUAN MEDIA AUDIOVISUAL TERHADAP HASIL BELAJAR IPS DITINJAU DARI MINAT OUTDOOR SISWA KELAS V SDN GUGUS 1 MASBAGIK UTARA LOMBOK TIMUR TAHUN PELAJARAN 2018/2019
}

\author{
Made Ayu Pransisca ${ }^{1}$, Alfi Zaidah ${ }^{2}$ \\ madeayupransisca@nusantaraglobal.ac.id ${ }^{1} .$, alpizaidah@ nusantaraglobal.ac.id ${ }^{2}$
}

${ }^{1,}$ Program Studi Pendidikan Guru Sekolah Dasar, Institut Pendidikan Nusantara Global, Indonesia, 83511

2,Program Studi Pendidikan IPA, Institut Pendidikan Nusantara Global, Indonesia, 83511

\begin{abstract}
Abstrak
Penelitian ini bertujuan untuk menyelidiki pengaruh model pembelajaran web (e-Learning) dari minat outdoor siswa kelas V SDN Gugus 1 Masbagik Utara Lombok Timur. Penelitian ini menggunakan pendekatan eksperimen semu dengan rancangan post test two group faktorial design. Populasi dalam penelitian ini sebanyak 143 orang siswa. Sampel penelitian ini berjumlah 76 orang siswa ditentukan dengan teknik random sampling. Data minat outdoor siswa dikumpulkan dengan kuisioner dan data hasil belajar IPS dikumpulkan dengan tes. Data dianalisis menggunakan Anava AB berbantuan SPSS 16.00 for windows. Hasil penelitian menunjukkan bahwa: 1) Terdapat perbedaan yang signifikan hasil belajar IPS antara siswa yang mengikuti pembelajaran dengan model pembelajaran web (e-Learning) bernuansa lingkungan berbantuan media audiovisual dan siswa yang mengikuti pembelajaran konvensional (FA hitung $=14,489$, dengan $\mathrm{p}<0,05)$, 2) Terdapat pengaruh interaksi yang signifikan antara model pembelajaran web (e-Learning) bernuansa lingkungan berbantuan media audiovisual dan minat outdoor terhadap hasil belajar IPS siswa (FA hitung $=36,202$, dengan $\mathrm{p}<0,05$ ), 3) Pada siswa yang memiliki minat outdoor tinggi, terdapat perbedaan signifikan hasil belajar IPS antara siswa yang mengikuti pembelajaran dengan model pembelajaran web (e-Learning) bernuansa lingkungan berbantuan media audiovisual dan siswa yang mengikuti pembelajaran konvensional $\left.\left(t_{\text {hitung }}>t_{\text {tabel }}=6,934>1,980\right), 4\right)$ Pada siswa yang memiliki minat outdoor rendah, tidak terdapat perbedaan signifikan hasil belajar antara siswa yang mengikuti pembelajaran dengan model pembelajaran web (e-Learning) bernuansa lingkungan berbantuan media audiovisual dan siswa yang mengikuti pembelajaran konvensional $\left(\mathrm{t}_{\text {hitung }}<\mathrm{t}_{\text {tabel }}=\right.$ $1,561<1,980)$.
\end{abstract}

Kata Kunci : model Pembelajaran web (e-Learning), media Audiovisual, minat Outdoor, hasil Belajar.

\begin{abstract}
The purpose of this research was to explore The Effects of web (e-Learning) Learning Model Audiovisual Media Assisted on IPS Learning Outcomes Viewed from Outdoor Interest of VClass Students of SDN Gugus 1 North Masbagik, East Lombok.This research used quasiexperimental approach with the post test two group factorial design. The population of this research was 143 students. The sample of this research amounted to 76 students determined by random sampling technique. The data of students' outdoor interest was collected by using questionnaire and the data of IPS learning result was collected by using test. The data were analyzed using SABS assisted Anava AB 16.00 for windows. The results showed that: 1) There was a significant difference of the IPS learning outcomes between the students who followed the learning model with web (e-Learning) model of audiovisual media-assisted environment and the students who followed the conventional learning ( $\mathrm{FA}=14,489$, with $\mathrm{p}<0.05)$; 2) There was a significant interaction effect between web (e-Learning) learning model nuanced audiovisual media environment and outdoor interest toward student's learning result of IPS (FA count $=36,202$, with $p<0,05$ ); 3). For the students with high outdoor interest, there was significant differences in IPS learning outcomes
\end{abstract}


between the students who followedthe learning model with web (e-Learning) learning nuanced audiovisual media environment and students who followed conventional learning (tcount> 6.934> 1.980); 4). For the students with low outdoor interest, there was no significant difference in learning outcomes between the students who followed the learning model with web (e-Learning) learning nuanced audiovisual media environment and the students who followed conventional learning (tcount $<$ ttabel $=1,561<1,980$ ).

Keywords: web (e-Learning) Learning Model, Audiovisual Media, Outdoor Interests, Learning Outcomes.

\section{PENDAHULUAN}

Pendidikan merupakan usaha sadar dan terencana untuk mewujudkan suasana belajar dan proses pembelajaran agar siswa secara aktif mengembangkan dan meningkatkan potensi yang dimilikinya. Setiap manusia dilahirkan mempunyai potensi dalam dirinya, oleh sebab itu perlu dilakukan suatu usaha yang dapat membantu manusia mengenali potensi dirinya dan mengembangkan bakatnya. Pernyataan ini didukung oleh Ki Hajar Dewantara (dalam Dantes, 2014) yang menyatakan bahwa "pendidikan adalah memanusiakan manusia [1].

Menurut Ratumanan (dalam Dewi dkk,

2014) menyatakan bahwa "pembelajaran merupakan suatu kondisi di mana guru membantu siswa untuk membangun pengetahuan dan kemampuannya sendiri melalui konsep internalisasi sehingga pengetahuan itu dapat terkontruksi kembali" [2]. Untuk menciptakan suatu pembelajaran yang berorientasi pada keterlibatan dan aktivitas siswa, diperlukan kemampuan guru dalam mendesain, mengimplementasikan, dan menyeluruh (holistik) untuk dapat mendorong siswa mengembangkan kompetensi yang dipelajari dengan kemampuannya sendiri. Selain itu, pemanfaatan media yang tepat dan menarik dapat membantu dalam menciptakan situasi pembelajaran yang bersifat interaktif dengan melibatkan aktivitas siswa di dalamnya. Salah satu inovasi dalam mendesain pembelajaran yang bisa dilakukan adalah dengan penerapan model pembelajaran web (e-Learning) bernuansa lingkungan berbantuan media audiovisual ditinjau dari minat outdoor. Model pembelajaran web (e-Learning) populer dengan sebutan Web - Based Education (WBE) atau kadang disebut e-learning (electronic learning) dapat didefinisikan sebagai aplikasi teknologi web dalam dunia pembelajaran untuk sebuah proses pendidikan. Secara sederhana dapat dikatakan bahwa semua pembelajaran dilakukan dengan memanfaatkan teknologi internet dan selama proses belajar dirasakan terjadi oleh yang mengikutinya, maka kegiatan itu dapat disebut sebagai pembelajaran berbasis web.

Zaman yang maju akan ilmu pengetahuan dan teknologi, khususnya teknologi informasi, sangat berpengaruh terhadap penyusunan dan implementasi strategi pembelajaran. Melalui kemajuan tersebut para guru dapat menggunakan berbagai media sesuai dengan kebutuhan dan tujuan pembelajaran. "Melalui penggunaan media komunikasi seperti media pembelajaran audiovisual, yang tidak hanya dapat mempermudah dan mengefektifkan proses pembelajaran, akan tetapi juga dapat membuat proses pembelajaran lebih menarik" Sanjaya (dalam Utomo dan Poedjiastoeti, 2014) [3].

Media audiovisual merupakan media perantara atau penggunaan materi melalui pandangan dan pendengaran sehingga membangun kondisi yang dapat membuat siswa menjadi lebih aktif dalam belajar sebagaimana dikatakan oleh Dewi dkk (2014). Pembelajaran yang baik dan menyenangkan tidak hanya terjadi di dalam kelas di luar kelas pun kita bisa menciptkan kondisi belajar yang menyenangkan salah satunya dengan pembelajaraan Outdoor, siswa akan lebih aktif untuk belajar dan pembelajaran dapat bermakna bagi siswa [4]. Dalam penelitian ini minat Outdoor didefinisikan sebagai suatu kecenderungan atau keinginan hati yang tinggi untuk memilih sesuatu kegiatan yang berhubungan dengan alam seperti binatang, tumbuhan dan bendabenda di sekitar kita berdasarkan situasi yang dihubungkan dengan keinginan-keinginan atau kebutuhan-kebutuhannya sendiri menurut Winkel (dalam Dewi dkk, 2014). Oleh karena itu, apa yang dilihat seseorang sudah tentu akan membangkitkan minatnya sejauh apa yang 
dilihat mempunyai hubungan dengan kepentingannya sendiri. Dalam minat outdoor ini terdapat tiga indikator yaitu: 1) ketertarikan; 2) perhatian; 3) dan ketersediaan meluangkan waktu.

Saat ini masih sangat sulit bagi guru mengetahui prilaku dalam proses pembelajaran dan hasil belajar siswa khususnya dalam pelajaran IPS. Pembelajaran IPS SD bertujuan untuk membekali siswa dalam pengetahuan dan kemampuan tentang kehidupan bermasyarakat, mulai dari berkomunikasi, berinteraksi, bekerjasama hingga berkompetensi. Selain itu, pembelajaran IPS diharapkan dapat membentuk siswa yang sadar akan nilai-nilai sosial dan kemanusiaan. Dengan demikian, hendaknya dalam pembelajaran IPS, siswa dibawa langsung ke dalam lingkungan sosial dan kehidupan bermasyarakat. Fakta dilapangan membuktikan bahwa kualitas pendidikan maupun kualitas proses pembelajaran IPS masih tidak sesuai dengan harapan pemerintah, salah satunya di SDN kelas V gugus 1 Masbagik Utara. Pada pembelajaran IPS sering kali hasil belajar siswa masih rendah, masih banyak siswa yang nilainya di bawah Kriteria Ketuntasan Minimal (KKM), mengenai rendahnya hasil belajar IPS berdasarkan data hasil observasi dan wawancara yang peneliti lakukan, dapat diidentifikasi bahwa terdapat beberapa gejala/faktor yang menyebabkan hasil belajar IPS siswa, yaitu (1) peserta didik kurang bisa memberikan tanggapan terhadap hasil diskusi. (2) masih banyak guru yang menerapkan model pembelajaran konvensional. (3) model dan penggunaan media yang digunakan guru masih belum memperhatikan pemahaman siswa. (4) siswa jarang dilatih untuk memecahkan masalah. (5) penilaian masih terfokus pada penilain kognitif saja. Berdasarkan paparan di atas membuktikan bahwa masih rendahnya hasil belajar IPS siswa.

Menyadari adanya permasalahan yang ditemukan di Sekolah Dasar Gugus I maka salah satu upaya/solusi yang dapat ditawarkan untuk meningkatkan hasil belajar IPS siswa adalah dengan menerapkan kegiatan dan bahan pembelajaran yang dapat menciptakan pembelajaran yang efektif. Pembelajaran tidak hanya fokus pada pemberian kemampuan pengetahuan teoritis, tetapi bagaimana agar pengalaman belajar peserta didik senantiasa terkait dengan permasalahan aktual yang terjadi di lingkungannya (Rusman, 2011) [5]. Kegiatan dan bahan pembelajaran harus sesuai dengan lingkungan peserta didik serta terkait pengalamannya dari interaksi dengan lingkungan, sehingga pembelajaran harus berisi bahan dan kegiatan pembelajaran yang memungkinkan peserta didik belajar untuk mengeksplorasi lingkungannya secara aktif. Media pembelajaran yang berbantuan pada lingkungan dapat diterapkan dalam pembelajaran IPS. Pembelajaran yang dapat memungkinkan siswa untuk belajar menyenangkan dan inovatif adalah Model pembelajaran web (e-Learning) merupakan model pembelajaran yang sangat mudah di pahami peserta didik karena pembelajaran web (e-Learning) menawarkan kecepatan dan tidak terbatasnya tempat dan waktu untuk mengakses informasi. Kegiatan belajar dapat dengan mudah dilakukan oleh peserta didik kapan saja dan dimana saja dirasakan aman oleh peserta didik tersebut. Batas ruang, jarak dan waktu tidak lagi menjadi masalah yang rumit untuk dipecahkan. (Rusman, 2011). Beranjak dari paradigma tersebut, dilaksanakan sebuah penelitian dengan menggunakan model pembelajaran web (eLearning) bernuansa lingkungan berbantuan media audiovisual ditinjau dari minat outdoor, maka peneliti memasukkan ide ini ke dalam penelitian yang berjudul "Pengaruh Model Pembelajaran web (e-Learning) Bernuansa Lingkungan Berbantuan Media Audiovisual Terhadap Hasil Belajar IPS Ditinjau dari Minat Outdoor Siswa Kelas V SDN Gugus 1 Masbagik Utara Lombok Timur Tahun Pelajaran 2018/2019".

Mengingat masalah tersebut sangat penting, maka dilakukan penelitian dengan tujuan: 1) Untuk menganalisis dan mendeskripsikan perbedaan hasil belajar IPS antara siswa yang mengikuti model pembelajaran web (e-Learning) bernuansa lingkungan berbantuan media audiovisual 
dengan siswa yang mengikuti model pembelajaran konvensional, 2) Untuk menganalisis dan mendeskripsikan pengaruh interaksi antara implementasi model pembelajaran dengan minat Outdoor terhadap hasil belajar IPS siswa kelas V SDN Gugus 1 Masbagik Utara, 3) Untuk menganalisis dan mendeskripsikan siswa yang memiliki minat Outdoor tinggi, apakah terdapat perbedaan hasil belajar IPS antara siswa yang mengikuti model pembelajaran web (e-Learning) bernuansa lingkungan berbantuan media audiovisual dengan siswa yang mengikuti model pembelajaran konvensional, 4)Untuk menganalisis dan mendeskripsikan siswa yang memiliki minat Outdoor rendah, apakah terdapat perbedaan hasil belajar IPS antara siswa yang mengikuti model pembelajaran web (e-Learning) bernuansa lingkungan berbantuan media audiovisual dengan siswa yang mengikuti model pembelajaran konvensional.

\section{METODE}

Penelitian ini dilaksanakan di Gugus I Tahun Pelajaran 2018/2019. Jenis penelitian ini dikategorikan penelitian faktorial $2 \times 2$. Desain penelitian adalah faktorial $2 \times 2$ dengan menggunakan kelompok eksperimen (model pembelajaran web (e-Learning) bernuansa lingkungan berbantuan media audiovisual ditinjau dari minat outdoor) dan kelompok kontrol (model pembelajaran konvesional). Populasi dalam penelitian ini adalah seluruh siswa kelas V Gugus I Kecamatan Lombok Timur Kabupaten Masbagik. Teknik pengambilan sampel dengan random sampling. Hasil pemilihan sampel menetapkan bahwa siswa SDN 1 Masbagik Utara dan SDN 4 Masbagik Utara yang secara keseluruhan berjumlah 61 siswa terpilih menjadi sampel untuk kelas eksperimen. Sedangkan, SDN 2 Masbagik Utara dan SDN 9 Masbagik Utara yang secara keseluruhan berjumlah 56 siswa terpilih menjadi sampel untuk kelas kontrol.Variabel bebas dalam penelitian ini berupa model pembelajaran web (e-Learning) bernuansa lingkungan berbantuan media audiovisual dan model pembelajaran konvensional, variabel terikatnya berupa hasil belajar IPS sedangkan variabel moderator adalah minat outdoor. Teknik pengumpulan data yang digunakan dalam penelitian ini adalah teknik tes dan non-tes. Teknik tes digunakan untuk mengambil data hasil belajar IPS, dalam penelitian ini tes yang digunakan adalah tes objektif dengan bentuk pilihan ganda dan Teknik non-tes dalam penelitian ini dengan menggunakan lembar kuesioner minat outdoor siswa dengan modifikasi dari skala Likert.

Analisis data yang digunakan pada penelitian ini analisis statistik deskriptif, yang artinya bahwa data dianalisis dengan menghitung nilai rata-rata, modus, median, standar deviasi, varian, skor maksimum, dan skor minimum. Dalam penelitian ini data disajikan dalam bentuk grafik histogram. Teknik yang digunakan untuk menganalisis data guna menguji hipotesis penelitian adalah ANAVA $A B$. Sebelum dilakukan analisis data, maka dilakukan uji normalitas sebaran data dengan menggunakan uji Kolmogorov-smirnov, uji homogenitas varians dengan uji Levene's, dan uji korelasi antar variabel terikat (kolinieritas) dengan menggunakan product moment.

\section{HASIL DAN PEMBAHASA}

Perbedaan Hasil Belajar IPS Antara Siswa Yang Mengikuti Pembelajaran Dengan MODEL WEB (E-LEARNING) Bernuansa Lingkungan Berbantuan Media Audiovisual Dengan Siswa Yang Mengikuti Pembelajaran Dengan Pendekatan Konvensional

Berdasarkan hasil temuan dalam penelitian ini, memiliki nilai $\mathrm{F}_{\mathrm{A}}$ hitung $=14,489$ dengan $\mathrm{p}<0,05$. Dengan demikian, hipotesis nol $\left(\mathrm{H}_{0}\right)$ yang menyatakan tidak terdapat perbedaan hasil belajar IPS antara siswa yang mengikuti pembelajaran dengan model web (eLearning) bernuansa lingkungan berbantuan media audiovisual dengan siswa yang mengikuti pembelajaran dengan pendekatan konvensional, "ditolak". Dengan perkataan lain dapat ditarik kesimpulan bahwa terdapat perbedaan hasil belajar IPS antara siswa yang mengikuti pembelajaran dengan model web (e-Learning) bernuansa lingkungan berbantuan media audiovisual dengan siswa yang mengikuti pembelajaran dengan pendekatan konvensional. 
Penelitian lain yang mendukung temuan ini adalah Purwono dkk (2014) yang menyatakan bahwa, terdapat pengaruh model pembelajaran terhadap hasil belajar IPA, terkait model pembelajaran, model web (e-Learning) lebih baik dari model konvensional. Hal ini dapat dilihat bahwa nilai rata-rata model web $(e-$ Learning) lebih tinggi dari model konvensional [6].

Hal diatas dikuatkan oleh ciri dengan model Pembelajaran web (e-Learning), menurut Rusman (2011) model web (e-Learning) adalah pembelajaran yang berorientasi kepada pemanfaatan media dan teknologi dalam menciptakan proses dan aktivitas pembelajaran yang diinginkan. Pemanfaatan model desain pembelajaran web (e-Learning) perlu dilakukan tahap demi tahap (sistematik) dan menyeluruh (holistik) agar dapat memberikan hasil yang optimal yaitu terciptanya pembelajaran sukses. Belajar IPS tidak hanya sekadar belajar tentang konsep-konsep tetapi belajar secara bermakna. Bermakna dalam hal ini siswa tahu tujuan mereka belajar IPS. Siswa belajar bermakna jika materi dalam pembelajarannya dikaitkan dengan kehidupan nyata yang dekat dengan keseharian siswa. Salah satu tujuan belajar IPS adalah untuk memberikan pengetahuan yang merupakan kemampuan untuk melihat kembali atau mengenal kembali yang telah dialami dalam bentuk yang sama atau dialami sebelumnya (Lasmawan, 2010) [7].

Berdasarkan uraian di atas terlihat adanya kesesuaian antara belajar IPS dengan pembelajaran dengan model web (e-Learning). Di satu sisi proses pembelajaran IPS harus dapat menghubungkan antara konsep sosial dengan situasi dunia nyata yang pernah dialami ataupun yang pernah dipikirkan siswa.

\section{Pengaruh Interaksi Antara} Implementasi Model Pembelajaran Dengan Minat Outdoor Terhadap Hasil Belajar IPS Berdasarkan hasil temuan dalam penelitian ini, Tolak Ho jika $F_{\text {ABhitung }} \geq F_{\text {ABtabel }}$ pada taraf signifikan $\alpha=0,05$, sebaliknya terima Ho jika $F_{\text {ABhitung }} \leq \mathrm{F}_{\text {ABtabel }}$ pada taraf signifikan $\alpha$ $=0,05$. Berdasarkan hasil analisis Anava dua jalur diperoleh nilai $F_{\text {hitung }}=36,202$ dengan $p<$
0,05. Dengan demikian hipotesis nol (Ho) yang menyatakan tidak terdapat pengaruh interaksi antara implementasi model pembelajaran dengan minat outdoor terhadap hasil belajar IPS, “ditolak". Dengan demikian, dapat disimpulkan bahwa terdapat pengaruh interaksi antara implementasi model pembelajaran dengan minat outdoor terhadap hasil belajar IPS.

Temuan penelitian ini didukung oleh penelitian Ramadhani (2016) yang menyatakan Adanya pengaruh interaksi penggunan pembelajaran Outdoor Learning pada Model Discovery Learning terhadap hasil belajar siswa dibuktikan dengan nilai rata-rata posttest kelas eksperimen 84,0 kelas kontrol dengan rata-rata 69,4 .

Pembahasan terhadap hasil penelitian di atas beranjak dari kesesuaian antara minat outdoor dengan model pembelajaran yang harus diberikan untuk mencapai hasil belajar yang maksimal.

Menurut Dewi, Suarni dan Widiartini (2014) minat outdoor merupakan ketertarikan siswa terhadapat lingkungan di sekitarnya.

Berdasarkan karakteristik tersebut, model pembelajaran yang sesuai dengan karakteristik siswa adalah model web (eLearning) bernuansa lingkungan berbantuan media audiovisual yang memberikan siswa untuk menetapkan pengalaman belajar yang dapat membantu siswa dalam mencapai kompetensi yang diinginkan.

Berdasarkan hasil penelitian di atas, dapat disimpulkan bahwa model pembelajaran dengan minat outdoor sangat efektif diterapkan untuk meningkatkan hasil belajar dalam pembelajaran IPS siswa.

Perbedaan Hasil Belajar IPS Antara Siswa Yang Mengikuti Model Pembelajaran WEB (E-LEARNING) Dengan Siswa Yang Mengikuti Model Pembelajaran Konvensional Pada Minat Outdoor Tinggi

Berdasarkan hasil temuan dalam penelitian ini, perhitungan didapat $t_{\text {hitung }}$ sebesar 6,934 sedangkan $t_{\text {tabel }}$ pada taraf signifikansi $\alpha=$ 0,05 sebesar 1,980 . Hal ini berarti $t_{\text {hitung }}>t_{\text {tabel }}$ $(6,934>1,980)$. Dengan demikian Ho yang 
berbunyi tidak terdapat perbedaan hasil belajar IPS antara siswa yang mengikuti pembelajaran dengan model web (e-Learning) bernuansa lingkungan berbantuan media audiovisual dengan siswa yang mengikuti pembelajaran dengan pendekatan konvensional pada siswa dengan minat outdoor tinggi, "ditolak". Dengan demikian dapat disimpulkan bahwa terdapat perbedaan hasil belajar IPS antara siswa yang mengikuti pembelajaran dengan model web $(e-$ Learning) bernuansa lingkungan berbantuan media audiovisual dengan siswa yang mengikuti pembelajaran dengan pendekatan konvensional pada siswa dengan minat outdoor tinggi.

Temuan penelitian ini didukung oleh penelitian Purwono, Sri Yutmini dan Sri Anitah (2014) yang menyatakan hasil belajar siswa meningkat setelah guru menggunakan media Audiovisual.

Menurut Ngalimun (2016) minat menjadi modal utama bagi siswa untuk meningkatkan hasil belajar, hasil belajar siswa sangat bergantung pada model yang digunakan guru dan minat belajar siswa tersebut [8]. Model pembelajaran web (e-Learning) mengahadirkan suasana belajar yang bersifat student centre. Siswa menjadi aktif dalam belajar. Seluruh indra siswa dilibatkan secara maksimal sehingga lebih mudah memahami pelajaran. Selain itu pembelajaran web (e-Learning) juga menekankan pada keterlibatan lingkungan dalam proses pembelajaran. Hal ini berkaitan langsung dengan minat outdoor, yang mana minat outdoor merupakan ketertarikan siswa terhadapat lingkungan di sekitarnya. Minat outdoor yang tinggi sangat membantu siswa dalam memahami pelajaran IPS. Sedangkan, dalam pembelajaran yang menggunakan model pembelajaran web (e-Learning), guru memiliki peranan yang sangat penting. Hal ini dikarenakan guru mempunyai tanggung jawab yang besar terhadap penstrukturan materi. Pembelajaran yang berpusat pada guru, akan berimplikasi terhadap rendahnya hasil belajar siswa. Dengan demikian, dapat disimpulkan bahwa untuk siswa yang memiliki minat outdoor tinggi, dengan mengikuti pelajaran dengan model web (e-Learning) lebih baik daripada siswa yang mengikuti pelajaran dengan pembelajaran konvensional.

Perbedaan Hasil Belajar IPS Antara Siswa Yang Mengikuti Pembelajaran Dengan Model WEB (E-LEARNING) Bernuansa Lingkungan Berbantuan Media Audiovisual Dengan Siswa Yang Mengikuti Pembelajaran Dengan Pendekatan Konvensional Pada Siswa Dengan Minat Outdoor Rendah

Berdasarkan hasil temuan dalam penelitian ini, perhitungan didapat $t_{\text {hitung }}$ sebesar 1,561 sedangkan $t_{\text {tabel }}$ pada taraf signifikansi $\alpha=$ 0,05 sebesar 1,980 . Hal ini berarti $t_{\text {hitung }}<t_{\text {tabel }}$ $(1,561<1,980)$. Dengan demikian Ho yang berbunyi tidak terdapat perbedaan hasil belajar IPS antara siswa yang mengikuti pembelajaran dengan model web (e-Learning) bernuansa lingkungan berbantuan media audiovisual dengan siswa yang mengikuti pembelajaran dengan pendekatan konvensional pada siswa dengan minat outdoor rendah, "diterima". Dengan demikian dapat disimpulkan bahwa tidak terdapat perbedaan hasil belajar IPS antara siswa yang mengikuti pembelajaran dengan model web (e-Learning) bernuansa lingkungan berbantuan media audiovisual dengan siswa yang mengikuti pembelajaran dengan pendekatan konvensional pada siswa dengan minat outdoor rendah.

Temuan penelitian ini didukung oleh penelitian Ardiani (2014) yang menyatakan bahwa siswa yang memiliki minat outdoor rendah, tidak terdapat perbedaan hasil belajar antara siswa yang mengikuti pembelajaran dengan model pembelajaran Kuantum dan siswa yang mengikuti pembelajaran langsung [9].

Penerapan model pembelajaran web $(e-$ Learning), pada siswa yang memiliki minat outdoor rendah akan membuat siswa menjadi tertekan dalam mengikuti pelajaran karena pada model pembelajaran web (e-Learning), siswa dituntut untuk selalu aktif dalam mengkonstruk pengalaman belajarnya. Siswa yang memiliki minat outdoor rendah yang cenderung pasif akan lebih suka mengikuti langkah-langkah belajar yang teratur dan jelas karena mereka umumnya menerima materi pelajaran cenderung apa adanya. Mereka lebih terbiasa dengan 
belajar menghafal dan pembelajaran tanpa tekanan. Sehingga apabila diajarkan dengan model pembelajaran yang menggunakan pendekatan konstruktivisme akan menyulitkan bagi mereka (Pribadi, 2011) [10].

Sementara itu, apabila siswa yang memiliki minat outdoor rendah diberikan pembelajaran konvensional yaitu pembelajaran yang berpusat pada guru, yang pembelajarannya tanpa ada tekanan membuat mereka merasa lebih senang dan tenang dalam mengikuti proses pembelajaran karena mereka terbiasa dengan proses pembelajaran terbimbing. Jika siswa sudah merasa senang dengan apa yang mereka lakukan maka ini akan memicu mereka untuk berprestasi sehingga pembelajaran konvensional lebih cocok diberikan kepada siswa yang memiliki minat outdoor rendah. Berdasarkan paparan di atas, tampak bahwa setiap model pembelajaran memiliki keunggulan dan kelemahan, tergantung dari tingkat minat outdoor siswa. Siswa yang memiliki minat outdoor tinggi lebih baik diberikan pelajaran dengan menggunakan model pembelajaran web (e-Learning) sementara siswa yang memiliki minat outdoor rendah hendaknya diberikan pelajaran dengan menggunakan model pembelajaran konvensional.

\section{PENUTUP}

Berdasarkan temuan di atas, dapat disimpulkan bahwa model pembelajaran web (eLearning) bernuansa lingkungan berbantuan media audiovisual ditinjau dari minat outdoor memberikan pengaruh yang signifikan terhadap hasil belajar IPS pada siswa kelas V Sekolah Dasar di Gugus I Kecamatan Lombok Timur.

Berdasarkan temuan-temuan dan simpulan yang telah dikemukakan di atas, adapun saran yang dapat diajukan dalam penelitian ini adalah sebagai berikut. (1)Penelitian ini menunjukkan bahwa hasil belajar IPS siswa yang diajar dengan model web (e-Learning) bernuansa lingkungan berbantuan media audiovisual lebih baik daripada hasil belajar IPS siswa yang diajar dengan pembelajaran konvensional. Untuk itu, model web (e-Learning) bernuansa lingkungan berbantuan media audiovisual perlu dikenalkan dan dikembangkan lebih lanjut kepada para guru, siswa dan praktisi pendidikan lainnya sebagai salah satu aternatif pembelajaran. Proses pengenalan dan pengembangan model web (eLearning) bernuansa lingkungan berbantuan media audiovisual dapat dilakukan melalui seminar pembelajaran IPS, atau pelatihanpelatihan pembelajaran IPS.(2) Perlu merancang LKS terstruktur untuk anak dengan minat outdoor rendah dan melatih anak yang memiliki minat outdoor rendah agar dapat mendekati minat outdoor tinggi. (3)Penelitian lanjutan yang berkaitan dengan model web (eLearning) bernuansa lingkungan berbantuan media audiovisual perlu dilakukan dengan materi-materi IPS yang lain dengan melibatkan sampel yang lebih luas. Disamping itu, variabel lain seperti: intelegensi, minat, bakat, motivasi, konsep diri yang merupakan bagian yang tidak terpisahkan dari siswa perlu dikaji pengaruhnya terhadap pengembangan dan penerapan model web (e-Learning) bernuansa lingkungan berbantuan media audiovisual serta dampaknya terhadap hasil belajar IPS.

\section{DAFTAR RUJUKAN}

Dantes, N. 2014. Landasan Pendidikan Tinjauan dari Dimensi Makropedagogis. Singaraja: Universitas Pendidikan Ganesha Singaraja.

Dewi, S.R, dkk. 2014. Pengaruh Metode Pembelajaran Ekspresi Bebas Terhadap Hasil Belajar Seni Musik Ditinjau Dari Minat Outdoor Siswa Kelas XII SMA Negeri 1 Semarapura. Jurnal Ilmiah Pendidikan dan Pembelajaran. Program Pascasarjana Universitas Pendidikan Ganesha Volume 4 Tahun 2014. Terdapat pada: http://119.252.161.254/ejournal/index.php/jurnal_ep/article/view $\underline{1148}$ (diaskes tanggal 04 Desember 2019).

Utomo, A.P dan Poedjiastoeti. 2014. Pengembangan Media Audio-Visual Sel Volta Dan Sel Elektrolisis Pada Materi Redoks Di SMA Development Of Visual Auditory Media Voltaic Cells And Electrolysis Cells Subject Redox In Senior High School. Jurnal UNESA 
Journal of Chemical Education Volume 3 Nomor 3 Tahun 2014. Terdapat pada: http://jurnalmahasiswa.unesa.ac.id/inde x.php/journal-of-chemicaleducation/article/view/9769 $\quad$ (diaskes tanggal 25 November 2019).

Rusman. 2011. Model-model Pembelajaran Mengembangkan Profesionalisme Guru. Jakarta: Raja Grafindo Persada.

Purwono, J, dkk. 2014. Penggunaan Media Audio-Visual Pada Mata Pelajaran Ilmu Pengetahuan Alam Di Sekolah Menengah Pertama Negeri 1 Pacitan. Jurnal Program Studi Teknologi Pendidikan Pascasarjana UNS Volume 2 Nomor 2 Tahun 2014. Terdapat pada: https://media.neliti.com/media/publicati ons/142050-ID-penggunaan-mediaaudio-visual-pada-mata.pdf (diaskes tanggal 05 Desember 2019).

Lasmawan, I.W. 2010. Menelisik Pendidikan IPS dalam Perspektif Kontekstual Empiris. $\quad$ Singaraja: Mediakom Indonesia Press Bali.

Ramadhani, W.S. 2016. Penerapan Pembelajaran Outdoor Learning Process (Olp) Melalui Pemanfaatan Taman Sekolah Sebagai Sumber Belajar Materi Klasifikasi Tumbuhan Untuk Meningkatkan Hasil Belajar Siswa SMP. Jurnal OLP Tahun 2016. Terdapat pada: file:///C:/Users/user/Downloads/1531219317-1-PB.pdf (diaskes tanggal 22 November 2019).

Ngalimun.2016. Strategi dan Model Pembelajaran. Yogyakarta: Pressindo.

Ardiani, W, dkk. 2014. Model Brain Based Learning (BBL) Bernuansa Lingkungan Sekitar Berpengaruh Terhadap Hasil Belajar IPA Siswa Kelas V SD. Jurnal Mimbar PGSD Universitas Pendidikan Ganesha Jurusan PGSD Volume 2 Nomor 1 Tahun 2014. Terdapat pada: https://ejournal.undiksha.ac.id/index.php IJJPGSD/article/view/3016 (diaskes tanggal 20 Desember 2017).
Pribadi, B. 2011. Model ASSURE untuk Mendesain Pembelajaran Sukses. Jakarta: Dian Rakyat. 